\title{
FLEXPART v10.1 simulation of source contributions to Arctic black carbon
}

\author{
Chunmao Zhu ${ }^{1}$, Yugo Kanaya ${ }^{1}$, Masayuki Takigawa ${ }^{1}$, Kohei Ikeda ${ }^{2}$, Hiroshi Tanimoto ${ }^{2}$, Fumikazu Taketani ${ }^{1}$, \\ Takuma Miyakawa ${ }^{1}$, Hideki Kobayashi ${ }^{1}$, and Ignacio Pisso ${ }^{3}$ \\ ${ }^{1}$ Research Institute for Global Change, Japan Agency for Marine-Earth Science and Technology (JAMSTEC), \\ Yokohama 2360001, Japan \\ ${ }^{2}$ National Institute for Environmental Studies, Tsukuba 3058506, Japan \\ ${ }^{3}$ NILU - Norwegian Institute for Air Research, Kjeller 2027, Norway
}

Correspondence: Chunmao Zhu (chmzhu@jamstec.go.jp)

Received: 20 June 2019 - Discussion started: 24 September 2019

Revised: 7 January 2020 - Accepted: 18 January 2020 - Published: 10 February 2020

\begin{abstract}
The Arctic environment is undergoing rapid changes such as faster warming than the global average and exceptional melting of glaciers in Greenland. Black carbon (BC) particles, which are a short-lived climate pollutant, are one cause of Arctic warming and glacier melting. However, the sources of BC particles are still uncertain. We simulated the potential emission sensitivity of atmospheric BC present over the Arctic (north of $66^{\circ} \mathrm{N}$ ) using the FLEXPART (FLEXible PARTicle) Lagrangian transport model (version 10.1). This version includes a new aerosol wet removal scheme, which better represents particle-scavenging processes than older versions did. Arctic BC at the surface $(0-500 \mathrm{~m})$ and high altitudes $(4750-5250 \mathrm{~m})$ is sensitive to emissions in high latitude (north of $60^{\circ} \mathrm{N}$ ) and mid-latitude $\left(30-60^{\circ} \mathrm{N}\right)$ regions, respectively. Geospatial sources of Arctic $\mathrm{BC}$ were quantified, with a focus on emissions from anthropogenic activities (including domestic biofuel burning) and open biomass burning (including agricultural burning in the open field) in 2010. We found that anthropogenic sources contributed $82 \%$ and $83 \%$ of annual Arctic BC at the surface and high altitudes, respectively. Arctic surface BC comes predominantly from anthropogenic emissions in Russia $(56 \%)$, with gas flaring from the Yamalo-Nenets Autonomous Okrug and Komi Republic being the main source (31\% of Arctic surface BC). These results highlight the need for regulations to control $\mathrm{BC}$ emissions from gas flaring to mitigate the rapid changes in the Arctic environment. In summer, combined open biomass burning in Siberia, Alaska, and Canada contributes $56 \%-85 \%$ (75\% on average) and $40 \%-$
\end{abstract}

$72 \%(57 \%)$ of Arctic BC at the surface and high altitudes, respectively. A large fraction $(40 \%)$ of $\mathrm{BC}$ in the Arctic at high altitudes comes from anthropogenic emissions in East Asia, which suggests that the rapidly growing economies of developing countries could have a non-negligible effect on the Arctic. To our knowledge, this is the first year-round evaluation of Arctic BC sources that has been performed using the new wet deposition scheme in FLEXPART. The study provides a scientific basis for actions to mitigate the rapidly changing Arctic environment.

\section{Introduction}

The Arctic region has experienced warming at a rate twice that of the global average in recent decades (Cohen et al., 2014). The Arctic cryosphere has been undergoing unprecedented changes since the mid-1800s (Trusel et al., 2018). Glacier cover in Greenland reached its historically lowest level in summer 2012 (Tilling et al., 2015). Evidence indicates that the emissions and transport of greenhouse gases and aerosols to the Arctic region are contributing to such warming and melting of snow and ice (Keegan et al., 2014; Najafi et al., 2015). Short-lived climate pollutants such as black carbon (BC) particles (e.g., Sand et al., 2016; Yang et al., 2019), sulfate aerosol (Yang et al., 2018), tropospheric ozone, and methane greatly affect the Arctic climate (AMAP, 2015; Quinn et al., 2008). 
$\mathrm{BC}$ particles are emitted during incomplete combustion of fossil fuels, biofuels, and biomass. BC warms the atmosphere by direct absorption of solar radiation. The deposition of BC on snow and ice surfaces accelerates their melting through decreasing albedo, which contributes to the rapid loss of glaciers. In the Arctic region, ground-based observations have indicated that $\mathrm{BC}$ shows clear seasonal variations, with elevated mass concentrations in winter and spring (the so-called Arctic haze) and low values in summer (Law and Stohl, 2007). Such seasonal variations are explained by increased transport from lower latitudes in the cold season and increased wet scavenging in the warm season (Shaw, 1995; Garrett et al., 2011; Shen et al., 2017).

The presence of $\mathrm{BC}$ particles in the Arctic is mainly attributed to emissions in high-latitude regions outside the Arctic, such as northern Europe and Russia (Stohl, 2006; Brock et al., 2011). This is partly caused by the polar dome (Stohl, 2006), which is formed because of the presence of constant potential temperature near the surface. The emissions in high-latitude regions are transported to the Arctic region and trapped in the dome, which increases the surface concentration. Recently, Schmale et al. (2018) suggested that local emissions from within the Arctic are another important source, and these are expected to increase in the future.

Although numerous studies have been performed, results regarding regional contributions of $\mathrm{BC}$ sources in the Arctic are still inconclusive. For example, ground-based observations and Lagrangian transport model results reported by Winiger et al. (2016) showed that BC in Arctic Scandinavia is predominantly linked to emissions in Europe. Over the whole Arctic region (north of $66^{\circ} \mathrm{N}$ ), Russia contributes $62 \%$ to surface BC in terms of the annual mean (Ikeda et al., 2017). Gas flaring in Russia has been identified as a major (42\%) source of BC at the Arctic surface (Stohl et al., 2013). Xu et al. (2017) found that anthropogenic emissions from northern Asia contribute $40 \%-45 \%$ of Arctic surface BC in winter and spring. However, the results of some other studies have suggested that Russia, Europe, and southern Asia each contribute $20 \%-25 \%$ of $\mathrm{BC}$ to the low-altitude springtime Arctic haze (Koch and Hansen, 2005). Sand et al. (2016) found that the surface temperature in the Arctic is most sensitive to emissions in Arctic countries, and Asian countries contribute greatly to Arctic warming because of the large absolute amount of emissions. With these large disagreements among studies, it is thus necessary to unveil BC sources in the Arctic with high-precision simulations.

Various models have been used to investigate BC sources in the Arctic. Depending on the simulation method, these models are generally categorized as Lagrangian transport models (Hirdman et al., 2010; Liu et al., 2015; Stohl et al., 2013; Stohl, 2006), chemical transport models (CTMs; Ikeda et al., 2017, 2020; Qi et al., 2017; Shindell et al., 2008; Wang et al., 2011; Xu et al., 2017), and global climate models (GCMs; Ma et al., 2013; Koch and Hansen, 2005; Schacht et al., 2019; H. Wang et al., 2014) (Table 1). The treatment of wet-scavenging parameterizations is a key factor affecting the model performance, which determines the uncertainties related to BC particle removal (Kipling et al., 2013; Schacht et al., 2019; Q. Wang et al., 2014). The use of emission inventories is another important factor that affects the simulation results (Dong et al., 2019). The observations of BC that are used for model comparisons may be biased by a factor of 2 depending on the method used (Sinha et al., 2017; Sharma et al., 2017). There are still large uncertainties regarding the sources of BC in the Arctic with respect to emission sectors (anthropogenic sources and open biomass burning) and geospatial contributions (Eckhardt et al., 2015).

The FLEXible PARTicle dispersion model (FLEXPART) had been used to investigate the transport pathways and source contributions of BC in the Arctic (Stohl et al., 1998, 2013; Stohl, 2006). For the FLEXPART model up to version 9, wet removal was treated considering below-cloud and within-cloud scavenging processes (Hertel et al., 1995; McMahon and Denison, 1979), which depend on cloud liquid-water content, precipitation rate, and the depth of the cloud. However, clouds were parameterized based on relative humidity with unrealistic precipitation, clouds frequently extended to the surface, and at times no clouds could be found in grid cells (Grythe et al., 2017). Recently, version 10 of FLEXPART has been developed in which cloud is differentiated into liquid, solid, and mixed phase, and the cloud distribution is more consistent with the precipitation data (Grythe et al., 2017). This improvement in the cloud distribution and phase leads to a more realistic distribution of below-cloud and in-cloud scavenging events. In this study, we quantified region-separated sources of $\mathrm{BC}$ in the Arctic in 2010 by using FLEXPART v10.1. We first evaluated the model performance by comparing the results with those based on observations at surface sites. The source contributions of emission sectors and geospatial contributions were evaluated by incorporating the Arctic BC footprint into the emission inventories.

\section{Materials and methods}

\subsection{Transport model}

The FLEXPART model (version 10.1) was run in backward mode to simulate $\mathrm{BC}$ footprints in the Arctic region. The calculation of wet deposition was improved compared with those in previous versions because in-cloud scavenging and below-cloud scavenging of particles were separately calculated (Grythe et al., 2017). In previous versions of FLEXPART, in the in-cloud scavenging scheme, the aerosol scavenging coefficient depended on the cloud water content, which was calculated according to an empirical relationship with precipitation rate, in which all aerosols had the same nucleation efficiency (Hertel et al., 1995; Stohl et al., 2005). In the new version, the in-cloud scavenging scheme depends on the cloud water phase (liquid, ice, or mixed phase). Aerosols 


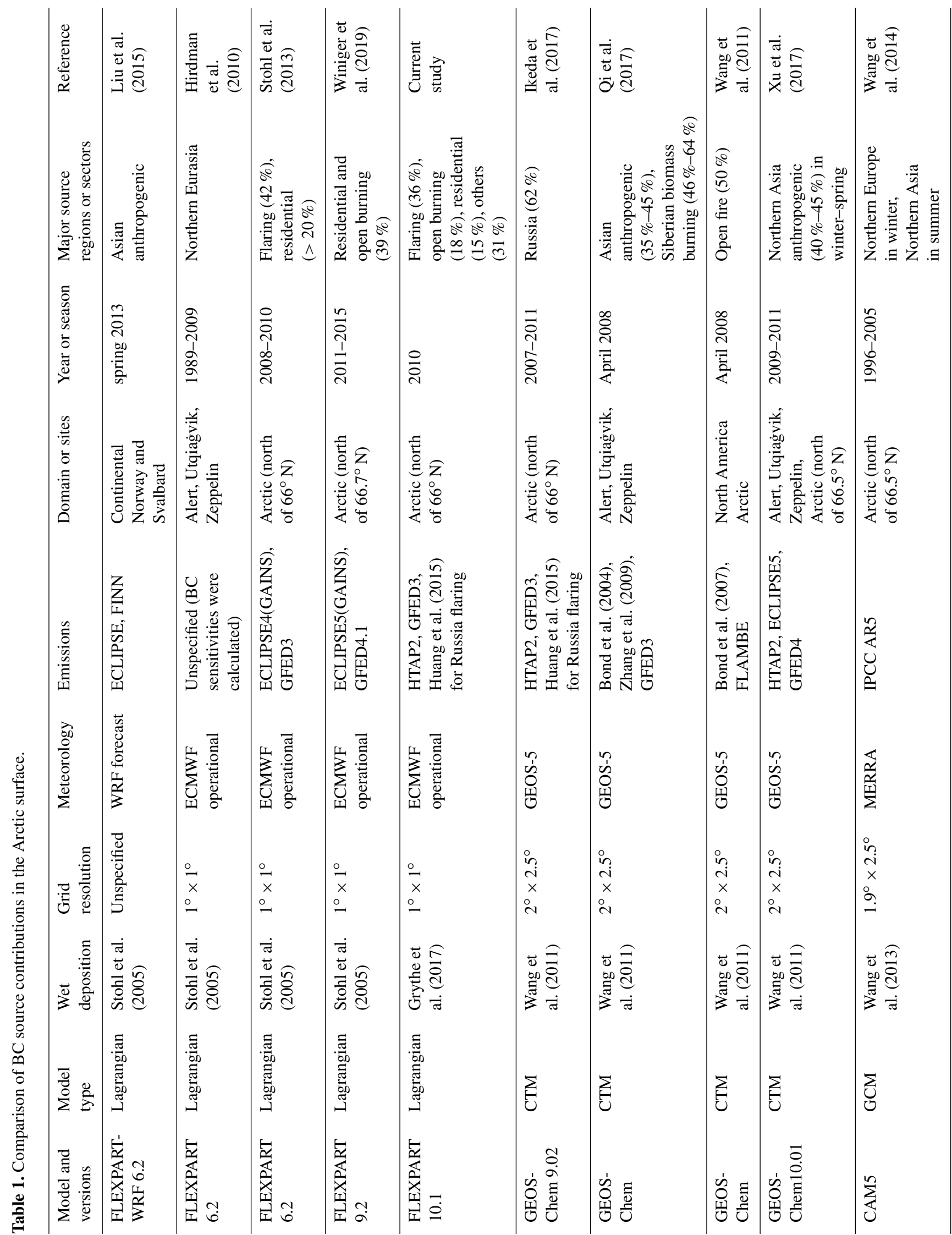


were set as ice nuclei for ice clouds and as cloud condensation nuclei for liquid-water clouds. For mixed-phase clouds, it was assumed that $10 \%$ of aerosols are ice nuclei and $90 \%$ are cloud condensation nuclei, because BC is much more efficiently removed in liquid-water clouds than in ice clouds (Cozic et al., 2007; Grythe et al., 2017). The below-cloud scavenging scheme can parameterize below-cloud removal as a function of aerosol particle size, precipitation type (snow or rain), and intensity. The biases produced in simulations using the new scheme are therefore smaller than those in the old scheme for wet deposition of aerosols, especially at high latitudes (Grythe et al., 2017).

The Arctic region is defined as areas north of $66^{\circ} \mathrm{N}$. The potential $\mathrm{BC}$ emission sensitivities at two heights in the Arctic region, i.e., the surface $(0-500 \mathrm{~m})$ and high altitudes (4750-5250 m), were simulated. The FLEXPART outputs were set as gridded retention times. We performed tests at 500,2000 , and $5000 \mathrm{~m}$, and chose $500 \mathrm{~m}$ as the upper boundary height of the model output. The model was driven with operational analytical data from the European Centre for Medium-Range Weather Forecasts (ECMWF) at a spatial resolution of $1^{\circ} \times 1^{\circ}$ with 61 vertical levels. Temporally, ECMWF has a resolution of $3 \mathrm{~h}$, with $6 \mathrm{~h}$ analysis and $3 \mathrm{~h}$ forecast time steps. The simulation period was set at $60 \mathrm{~d}$ backward starting from each month in 2010. The maximum lifetime of BC was set at $20 \mathrm{~d}$, because its suspension time in the upper atmosphere during long-range transport is longer than that at the surface level (Stohl et al., 2013). We implemented the wet deposition scheme in the backward calculations, but it was not represented in the default setting (FLEXPART v10.1, https://www.flexpart.eu/downloads, last access: 10 April 2017).

The chemistry and microphysics could not be resolved by FLEXPART. The model therefore ignores hydrophobic to hydrophilic state changes and size changes of $\mathrm{BC}$, and it assumes that all $\mathrm{BC}$ particles are aged hydrophilic particles. This may lead to an overestimation of $\mathrm{BC}$ removal and hence force underestimation of simulated $\mathrm{BC}$ concentration, especially of fossil fuel combustion sources where $\mathrm{BC}$ could be in the hydrophobic state for a few days. A logarithmic size distribution of BC with a mean diameter of $0.16 \mu \mathrm{m}$ and a standard deviation of 1.96, in accordance with our ship observations in the Arctic, was used (Taketani et al., 2016). The particle density was assumed to be $2000 \mathrm{~kg} \mathrm{~m}^{-3}$, and 1 million computational particles were randomly generated in the Arctic region for the backward runs.

Four ground-based observations made during the period 2007-2011 were used to validate the model performance. The potential $\mathrm{BC}$ emission sensitivity at 0 $500 \mathrm{~m}$ a.g.l. (above ground level) from a $0.1^{\circ}$ grid centered at each site was simulated. Other model parameterizations were consistent with those for the Arctic region, except that 200000 computational particles were released. 


\subsection{Emission inventories}

We focused on BC sources from anthropogenic emissions and open biomass burning. The Hemispheric Transport of Air Pollution version 2 inventory (HTAP2) for 2010 was used for monthly anthropogenic BC emissions (JanssensMaenhout et al., 2015), which include sectors from energy, industry, residential and transport. It is worth noting that the residential sector includes not only combustions of fossil fuels but also biofuels. However, as it has been reported that $\mathrm{BC}$ emissions in Russia were underestimated in HTAP2, we used the BC emissions reported by Huang et al. (2015) for Russia, in which the annual BC emissions were $224 \mathrm{Gg} \mathrm{yr}^{-1}$. For open biomass burning, we used the monthly BC emissions from the Global Fire Emissions Database version 3 inventory (GFED3) (van der Werf et al., 2010) for the purposes of intercomparison with other studies, as this version is widely used. The term "open biomass burning" here indicates burning of biomass in the open field as is determined by the remote sensing measurement basis, including forest, agricultural waste, peat fires, grassland and savanna, woodland, deforestation, and degradation, where biofuel burning for residential use is not included. Geospatial distributions of emissions from anthropogenic sources and open biomass burning in January and July are shown in Fig. S1 in the Supplement.

\subsection{Calculation of Arctic BC source contributions}

The source contributions to Arctic BC were derived by incorporating the gridded retention time into the column emission flux, which was derived from the emission inventories in each grid. Calculations for anthropogenic sources and open biomass burning were performed separately and the sum was used. For anthropogenic sources, the regions were separated into North America and Canada $\left(25-80^{\circ} \mathrm{N}, 50-170^{\circ} \mathrm{W}\right)$, Europe $\left(30-80^{\circ} \mathrm{N}, 0-30^{\circ} \mathrm{E}\right)$, Russia $\left(53-80^{\circ} \mathrm{N}, 30-180^{\circ} \mathrm{E}\right)$, East Asia $\left(35-53^{\circ} \mathrm{N}, 75-150^{\circ} \mathrm{E}\right.$ and $\left.20-35^{\circ} \mathrm{N}, 100-150^{\circ} \mathrm{E}\right)$, and others (the rest) (Fig. 1a). For open biomass burning sources, the regions were separated into Alaska and Canada $\left(50-75^{\circ} \mathrm{N}, 50-170^{\circ} \mathrm{W}\right)$, Siberia $\left(50-75^{\circ} \mathrm{N}, 60-180^{\circ} \mathrm{E}\right)$, and others (Fig. 1b).

\subsection{Observations}

BC levels simulated by FLEXPART were compared with those based on surface observations at four sites: Utqiagivik, USA (formerly Barrow) $\left(71.3^{\circ} \mathrm{N}, 156.6^{\circ} \mathrm{W} ; 11 \mathrm{~m}\right.$ a.s.1.); Alert, Canada $\left(82.5^{\circ} \mathrm{N}, 62.3^{\circ} \mathrm{W}\right.$; $210 \mathrm{~m}$ a.s.l.); Zeppelin, Norway $\left(78.9^{\circ} \mathrm{N}, 11.9^{\circ} \mathrm{E}\right.$; $478 \mathrm{~m}$ a.s.1.); and Tiksi, Russia $\left(71.6^{\circ} \mathrm{N}, 128.9^{\circ} \mathrm{E} ; 8 \mathrm{~m}\right.$ a.s.1.). Aerosol light absorption was determined by using particle soot absorption photometers (PSAPs) at Utqiagivik, Alert, and Zeppelin, and an Aethalometer at Tiksi. For PSAP measurements, the equivalent $\mathrm{BC}$ values were derived by using a mass absorption efficiency of $10 \mathrm{~m}^{2} \mathrm{~g}^{-1}$. The equivalent BC at Tiksi, which was determined with an Aethalometer, was obtained directly. These measurement data were obtained from the European Monitoring and Evaluation Programme and the World Data Centre for Aerosols database (http://ebas.nilu.no, last access: 1 December 2017) (Tørseth et al., 2012).

It is worth noting that uncertainties could be introduced by using different $\mathrm{BC}$ measurement techniques. An evaluation of three methods for measuring $\mathrm{BC}$ at Alert, Canada, indicated that an average of the refractory $\mathrm{BC}$ determined with a single-particle soot photometer (SP2) and elemental carbon (EC) determined from filter samples give the best estimate of BC mass (Sharma et al., 2017). Xu et al. (2017) reported that the equivalent $\mathrm{BC}$ determined with a PSAP was close to the average of the values for refractory $\mathrm{BC}$ and $\mathrm{EC}$ at Alert. In this study, we consider that the equivalent $\mathrm{BC}$ values determined with a PSAP at Utqiagivik, Alert, and Zeppelin to be the best estimate. There may be uncertainties in the equivalent BC observations performed with an Aethalometer at Tiksi because of co-existing particles such as light-absorbing organic aerosols, scattering particles, and dusts (Kirchstetter et al., 2004; Lack and Langridge, 2013). Interference by the filter and uncertainties in the mass absorption cross section could also contribute to the bias observed in measurements made with an Aethalometer at Tiksi.

\section{Results and discussion}

\subsection{Comparisons of simulations with $\mathrm{BC}$ observations at Arctic surface sites}

FLEXPART generally reproduced the seasonal variations in BC at four Arctic sites well (Pearson correlation coefficient, $R=0.53-0.80$, and root-mean-square error, $\mathrm{RMSE}=15.1-56.8 \mathrm{ng} \mathrm{m}^{-3}$ ) (Fig. 2). Winter maxima were observed for the four sites, while a secondary elevation was observed for Alert and Tiksi. At Utqiagivik, the observed high values of $\mathrm{BC}$ were unintentionally excluded during data screening in the forest fire season in summer (Stohl et al., 2013); the original observed BC is supposed to be higher as was reflected by the simulation. This seasonality is probably related to relatively stronger transport to the Arctic region in winter, accompanied by lower BC aging and inefficient removal, as simulated by older versions of FLEXPART (Eckhardt et al., 2015; Stohl et al., 2013).

From January to May at Utqiagivik and Alert, the mean BC values simulated by FLEXPART v10.1 were 32.2 and $31.2 \mathrm{ng} \mathrm{m}^{-3}$, respectively, which were $46 \%$ lower than the observations (59.3 and $58.2 \mathrm{ng} \mathrm{m}^{-3}$, respectively). This is probably related to the inadequate $\mathrm{BC}$ emission in the inventory, although seasonal variations in residential heating are included in HTAP2, which would reduce the simulation bias (Xu et al., 2017). Simulations by GEOS-Chem using the same emission inventories also underestimated BC levels at 
(a)

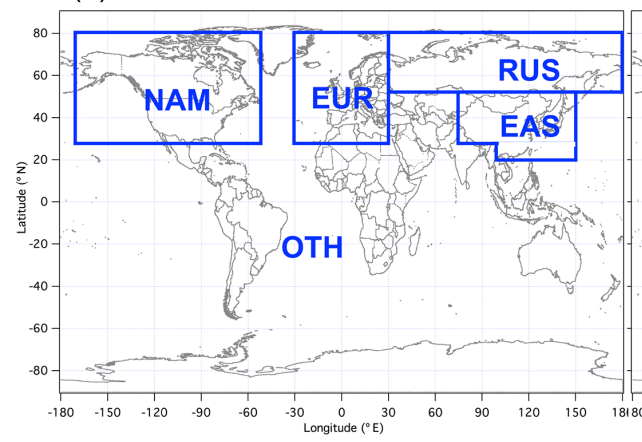

Anthropogenic sources

EUR: Europe

RUS: Russia

EAS: China, Japan, Korean Peninsula

NAM: North America, Alaska, Canada

OTH: others (b)

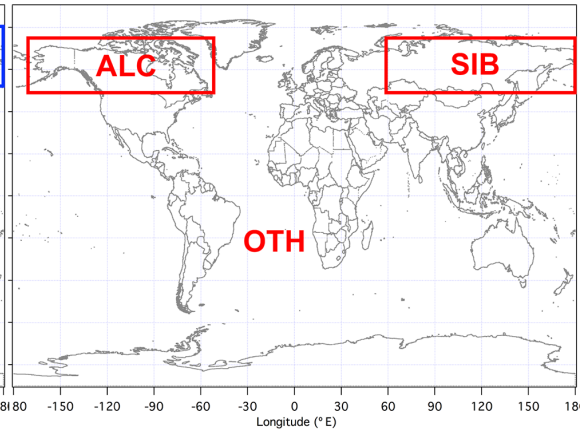

Biomass burning sources

SIB: Siberia

ALC: Alaska, Canada

OTH: others

Figure 1. Regional separation for quantification of BC in the Arctic from (a) anthropogenic and (b) open biomass burning sources.
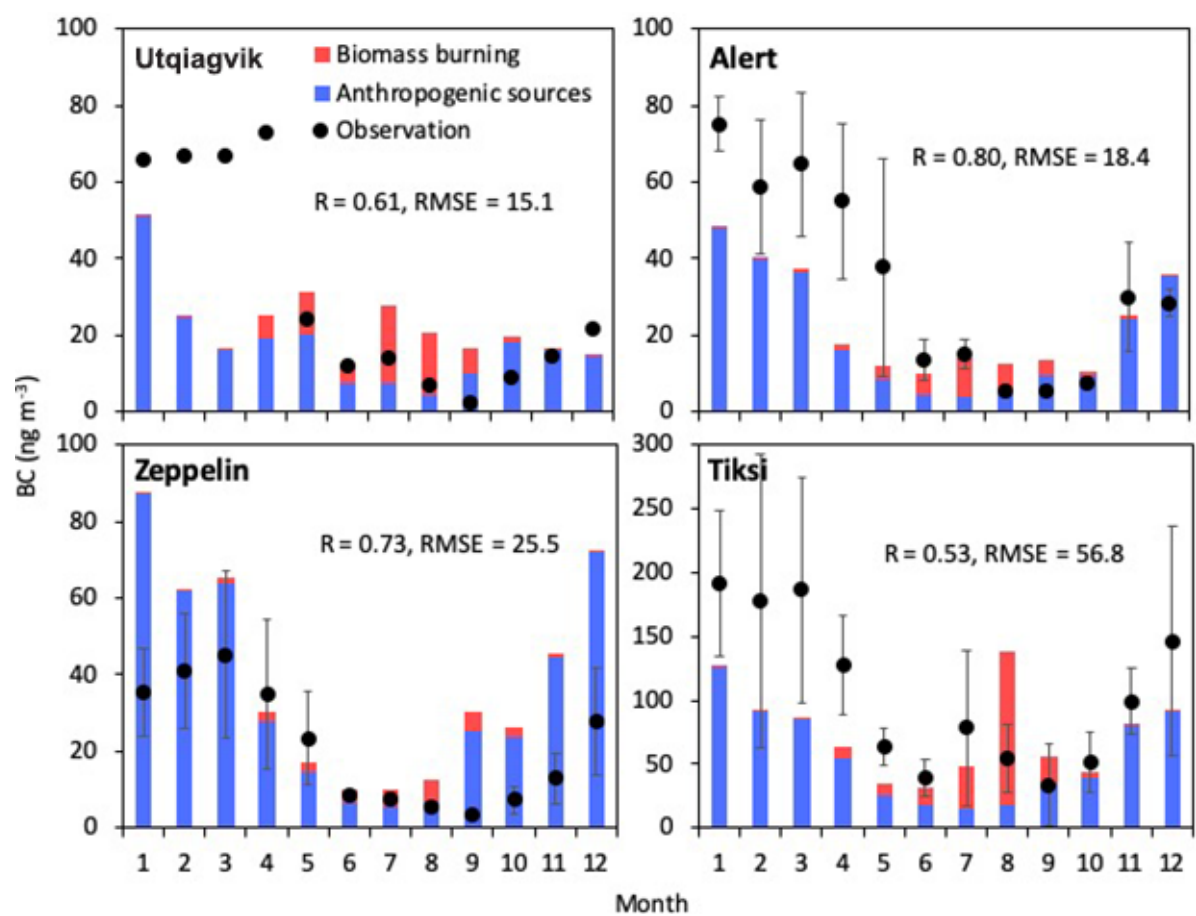

Figure 2. Observed (filled circles) and modeled (bars) seasonal variations in BC mass concentrations at Arctic sites. Contributions from anthropogenic sources (blue) and open biomass burning (red) in each month are shown. Monthly averages of observed (filled circles) and simulated (bars) BC were conducted for 2007-2011 at Alert, Canada $\left(82.5^{\circ} \mathrm{N}, 62.3^{\circ} \mathrm{W}\right)$, and Zeppelin, Norway $\left(78.9^{\circ} \mathrm{N}, 11.9^{\circ} \mathrm{E}\right)$; for 2009 at Utqiagivik, USA $\left(71.3^{\circ} \mathrm{N}, 156.6^{\circ} \mathrm{W}\right)$; and for $2010-2014$ at Tiksi, Russia $\left(128.9^{\circ} \mathrm{E}, 71.6^{\circ} \mathrm{N}\right) . R$ and RMSE indicate correlation coefficient and root-mean-square error $\left(\mathrm{ng} \mathrm{mm}^{-3}\right)$, respectively.

Utqiagivik and Alert (Ikeda et al., 2017; Xu et al., 2017). The underestimation by FLEXPART could also be partly contributed by the assumption that all particles are hydrophilic, where the BC scavenging could be overestimated. The cor- responding uncertainties are larger in winter months, when there are more sources from fossil fuel combustion.

At Zeppelin, the FLEXPART-simulated BC $\left(39.1 \mathrm{ng} \mathrm{m}^{-3}\right.$ for annual mean) was $85 \%$ higher than the observed value (21.1 $\mathrm{ng} \mathrm{m}^{-3}$ for annual mean), especially in winter $(112 \%$ 
higher). It has been reported that riming in mixed-phase clouds occurs frequently at Zeppelin (Qi et al., 2017). During the riming process, $\mathrm{BC}$ particles act as ice particles and collide with the relatively numerous water drops, which form frozen cloud droplets, and then snow is precipitated. This results in relatively efficient BC scavenging (Hegg et al., 2011). Such a process could not be dealt with by the model. At Tiksi, FLEXPART underestimated BC $\left(74.4 \mathrm{ng} \mathrm{m}^{-3}\right.$ for annual mean) in comparison with observation $\left(104.2 \mathrm{ng} \mathrm{m}^{-3}\right.$ for annual mean). Other than the hydrophilic BC assumption and underestimated $\mathrm{BC}$ emission in the simulation as in the cases for Utqiagivik and Alert, the observations at Tiksi by an Aethalometer could contain light-absorbing particles other than $\mathrm{BC}$, resulting in higher observed concentrations if compared with those obtained by SP2, EC, or PSAP.

Anthropogenic emissions are the main sources of $\mathrm{BC}$ at the four Arctic sites from late autumn to spring, whereas open biomass burning emissions make large contributions in summer. From October to April, anthropogenic emissions accounted for $87 \%-100 \%$ of BC sources at all the observation sites. At Utqiagivik, open biomass burning accounted for $35 \%-78 \%$ of BC in June-September (Fig. 2). There are large interannual variations in both observed and simulated BC (Fig. S2). In June-August 2010, the mean contributions of open biomass burning to $\mathrm{BC}$ were $6.3,2.4$, and 8.6 times those from anthropogenic sources at Alert, Zeppelin, and Tiksi, respectively. In this study, we focused on BC in the Arctic region in 2010.

\subsection{Potential emission sensitivity of Arctic BC}

The potential emission sensitivities (footprint) of Arctic BC showed different patterns with respect to altitude. The Arctic surface is sensitive to emissions at high latitudes $\left(>60^{\circ} \mathrm{N}\right)$. Air masses stayed for over $60 \mathrm{~s}$ in each of the $1^{\circ}$ grids from the eastern part of northern Eurasia and the Arctic Ocean before being transported to the Arctic surface in the winter, represented by January (Fig. 3a). In comparison, during the summer, represented by July, BC at the Arctic surface was mainly affected by air masses that originated from the Arctic Ocean and the Norwegian Sea (Fig. 3b). These results imply that local $\mathrm{BC}$ emissions within the Arctic regions, although relatively weak compared with those from the mid-latitude regions, could strongly affect Arctic air pollution. Local BC emissions are important in the wintertime because the relatively stable boundary layer does not favor pollution dispersion. Recent increases in anthropogenic emissions in the Arctic region, which have been caused by the petroleum industry and development of the Northern Sea Route, are expected to cause deterioration of air quality in the Arctic. Socioeconomic developments in the Arctic region would increase local $\mathrm{BC}$ emissions, and this will be a non-negligible issue in the future (Roiger et al., 2015; Schmale et al., 2018).
$\mathrm{BC}$ at high altitudes in the Arctic is more sensitive to midlatitude $\left(30-60^{\circ} \mathrm{N}\right)$ emissions, especially in wintertime. In January, air masses hovered over the Bering Sea and the North Atlantic Ocean before arriving at the Arctic (Fig. 3c). A notable corridor at $30-50^{\circ} \mathrm{N}$ covering Eurasia and the US was the sensitive region that affected $\mathrm{BC}$ at high altitudes in the Arctic in January. These results indicate that mid-latitude emissions, especially those with relatively large strengths from East Asia, eastern America, and Europe, could alter the atmospheric constituents at high altitudes in the Arctic. Central to east Siberia was the most sensitive region for $\mathrm{BC}$ at high altitudes in the Arctic in July (Fig. 3d). These results suggest that pollutants from frequent and extensive wildfires in Siberia in summer are readily transported to high altitudes in the Arctic. Boreal fires are expected to occur more frequently and over larger burning areas under future warming (Veira et al., 2016); therefore, the atmospheric constituents and climate in the Arctic could undergo more rapid changes.

\subsection{Seasonal variations and sources of Arctic surface BC}

Arctic surface $\mathrm{BC}$ showed clear seasonal variations, with a primary peak in winter-spring (December-March, 61.8$82.8 \mathrm{ng} \mathrm{m}^{-3}$ ) and a secondary peak in summer (July, $52.7 \mathrm{ng} \mathrm{m}^{-3}$ ). BC levels were relatively low in MayJune (21.8-23.1 $\mathrm{ng} \mathrm{m}^{-3}$ ) and September-November (34.1$40.9 \mathrm{ng} \mathrm{m}^{-3}$ ) (Fig. 4a). This seasonality agrees with observations and simulations at Alert, Tiksi, and Utqiagivik if considering the unintentional data exclusion (Stohl et al., 2013), and previous studies targeting the whole Arctic (Ikeda et al., 2017; Xu et al., 2017). Compared with the study reported by Stohl et al. (2013), the current work using the new scheme produced smaller discrepancies between the simulated data and observations. Although the simulation periods (monthly means for 2007-2011 in this study and for 2008-2010 in the old scheme) and the anthropogenic emission inventories (HTAP2 in this study and ECLIPSE4 in the previous study) are different, the new scheme shows potential for better representing $\mathrm{BC}$ transport and removal processes in the Arctic.

The annual mean Arctic BC at the surface was estimated to be $48.2 \mathrm{ng} \mathrm{m}^{-3}$. From October to April, anthropogenic sources accounted for $96 \%-100 \%$ of total BC at the Arctic surface. Specifically, anthropogenic emissions from Russia accounted for $61 \%-76 \%$ of total BC in October-May (56\% annually), and these were the dominant sources of Arctic BC at the surface. From an isentropic perspective, the meteorological conditions in winter favored the transport of pollutants from northern Eurasia to the lower Arctic, along with diabatic cooling and strong inversions (Klonecki et al., 2003). In comparison, open biomass burning from boreal regions accounted for $56 \%-85 \%$ ( $75 \%$ on average) of Arctic $\mathrm{BC}$ at the surface in summer; open biomass burning emissions from North America and Canada accounted for 54\% of total Arctic surface BC in June, and those from Siberia 


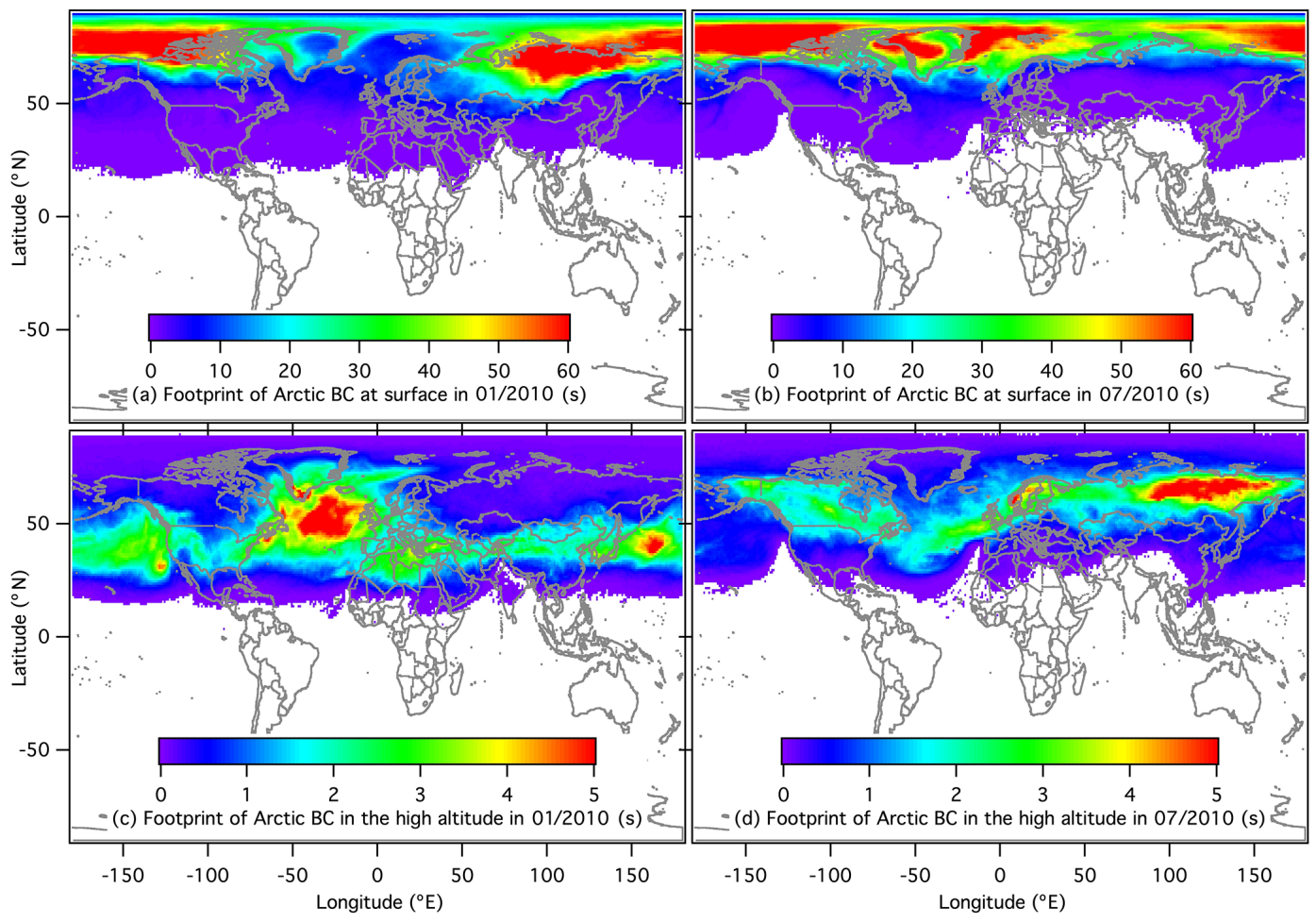

Figure 3. Footprints of Arctic BC shown as retention time(s) of (a) BC at surface (0-500 m) in January 2010, (b) BC at surface in July 2010, (c) BC at high altitudes (4750-5250 m) in January 2010, and (d) BC at high altitudes in July 2010.

(a)

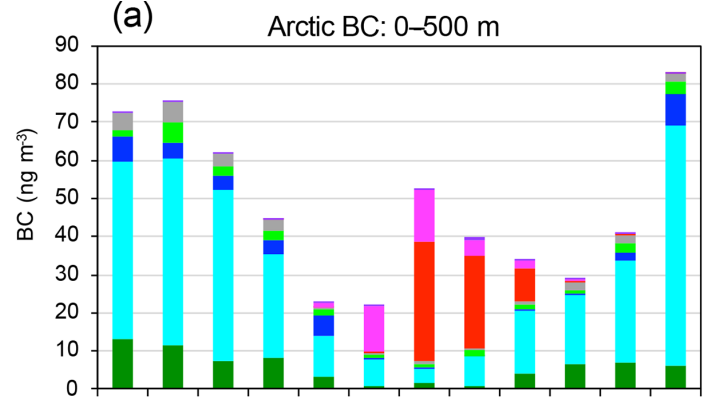

(c)

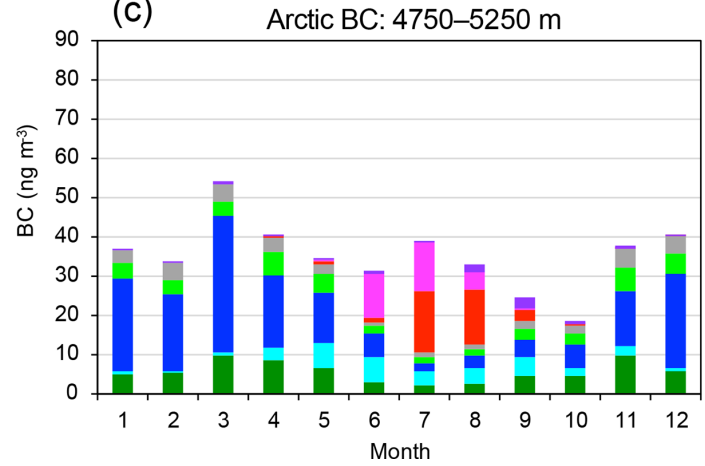

(b)

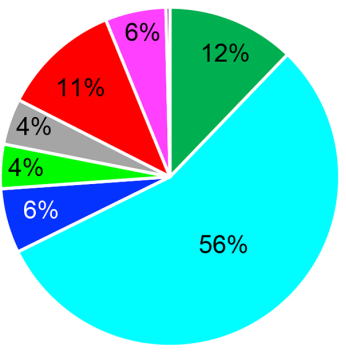

(d)

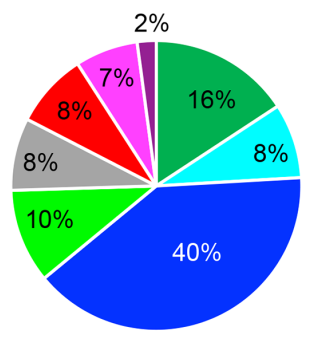

- AN_EUR

- AN_RUS

- AN_EAS

- AN_NAM

$\because$ AN OTH

- BB_SIB

- BB_ALC

- BB_OTH

Figure 4. Contributions of anthropogenic sources (prefixed "AN_" in the legend) and open biomass burning ("BB_") from each region to (a) seasonal variations in Arctic surface BC, (b) annual mean Arctic surface BC, (c) seasonal variations in Arctic BC at high altitudes, and (d) annual mean of Arctic BC at high altitudes. 
accounted for $59 \%-61 \%$ in July-August. Wildfires in the boreal forests in summer had a major effect on air quality in the Arctic.

On an annual basis, anthropogenic sources and open biomass burning emissions accounted for $82 \%$ and $18 \%$, respectively, of total Arctic surface BC. In which, gas flaring and residential burning (including burning of fossil fuels and biofuels) are accounting for $36 \%(28 \%-57 \%$ in October-March) and $15 \%$ (13\%-25\% in October-March), respectively (Fig. 5a and b). Our results support Stohl et al. (2013) such that residential combustion emissions, especially in winter, are important sources of Arctic BC (Table 1). We estimated a contribution of gas flaring to Arctic surface BC of $17.5 \mathrm{ng} \mathrm{m}^{-3}$ ( $36 \%$ of total). In comparison, the value was estimated as $11.8 \mathrm{ng} \mathrm{m}^{-3}$ using an average Arctic surface BC of $28 \mathrm{ng} \mathrm{m}^{-3}$ and a fraction from gas flaring of $42 \%$ evaluated by earlier versions of FLEXPART (Stohl et al., 2013; Winiger et al., 2019). The different contribution could be partly attributed to the difference in gas flaring emission inventory. BC emission from gas flaring in Russia by Huang et al. (2015) was used in the current study, where total BC emission from gas flaring in Russia in 2010 was ca. $81.1 \mathrm{kt}$, which was larger than the estimate of ca. $64.9 \mathrm{kt}$ by the GAINS inventory (Klimont et al., 2017) used by Stohl et al. (2013). Moreover, adopting the ECLIPSEv5 inventory as was used by Winiger et al. (2019), we estimated that gas flaring was contributing $14.4 \mathrm{ng} \mathrm{m}^{-3}$ to Arctic surface BC using FLEXPART v10.1, a value $22 \%$ higher than those obtained using FLEXPART v9. This difference could be attributed to the improvement of the wet-scavenging scheme by FLEXPART v10.1.

A recent study based on isotope observations at the Arctic sites and FLEXPART v9.2 simulation suggested that open biomass burning, including open field burning and residential biofuel burning, contributed $39 \%$ to annual BC in 20112015 (Winiger et al., 2019) (Table 1). In comparison, we estimated that residential burning and open biomass burning together account for $33 \%$ of total Arctic surface BC. As the residential burning in our study includes burning of both biofuels and fossil fuels, our results indicated that biomass burning has a relatively smaller contribution. Other than the differences in $\mathrm{BC}$ removal treatment between different versions of the model, the contribution difference could also be attributed to the different emission inventories and years (2010 versus 2011-2015).

The geospatial contributions of anthropogenic sources and open biomass burning emissions can be further illustrated by taking January and July as examples. In January, high levels of anthropogenic emissions from Russia (contributing $64 \%$ of Arctic surface BC), Europe (18\%), and East Asia (9\%) were identified (Fig. 6a). Specifically, YamaloNenets Autonomous Okrug in Russia, which has the largest reserves of Russia's natural gas and oil (Filimonova et al., 2018), was the most notable emission hotspot, which suggests gas-flaring sources. The Komi Republic in Russia was also identified as a strong anthropogenic emitter contributing to Arctic surface BC. These gas-flaring industrial regions in Russia $\left(58-69^{\circ} \mathrm{N}, 68-81^{\circ} \mathrm{E}\right)$ together contributed $33 \%$ and $31 \%$ of Arctic surface BC for January and the annual mean, respectively. Recently, Dong et al. (2019) evaluated BC emission inventories using GEOS-Chem and proposed that using the inventory compiled by Huang et al. (2015) for Russia, in which gas flaring accounted for $36 \%$ of anthropogenic emissions, had no prominent impact on the simulation performance in Russia or the Arctic. They suggested that the use of a new global inventory for $\mathrm{BC}$ emissions from natural gas flaring would improve the model performance (Huang and $\mathrm{Fu}, 2016)$. These results suggest that inclusion of $\mathrm{BC}$ emissions from gas flaring on the global scale is necessary for further BC simulations.

In Europe, a relatively high contribution of anthropogenic emissions to Arctic surface BC in January was made by Poland $\left(50-55^{\circ} \mathrm{N}, 15-24^{\circ} \mathrm{E}\right.$; contributing $4 \%$ of Arctic surface $\mathrm{BC}$ ) because of relatively large emission fluxes in the region (Fig. S1a). Anthropogenic emissions from eastern China, especially those north of $\sim 33^{\circ} \mathrm{N}\left(33-43^{\circ} \mathrm{N}, 109-\right.$ $\left.126^{\circ} \mathrm{E}\right)$, contributed perceptibly ( $5 \%$ ) to Arctic surface BC.

In July, contributions from anthropogenic sources shrank to those from Yamalo-Nenets Autonomous Okrug and Komi Republic in Russia, and contributed a lower fraction (3\% of Arctic surface BC) (Fig. 6b). Few open biomass burning sources contributed in January (Fig. 6c), but contributions from open biomass burning to Arctic surface BC in July can be clearly seen, mainly from the far east of Russia, Canada, and Alaska (Fig. 6d). Open biomass burning emissions from Kazakhstan, southwest Russia, southern Siberia, and northeast China also contributed to Arctic surface BC, although at relatively low strengths (Figs. 5d and S1d). However, the contributions from open biomass burning could be higher, as the MODIS burned area, the basis of GFED emission inventories, was underestimated for northern Eurasia by $16 \%$ (Zhu et al., 2017). Evangeliou et al. (2016) estimated a relatively high transport efficiency of $\mathrm{BC}$ from open biomass burning emissions to the Arctic, which led to a high contribution, i.e., $60 \%$, from such sources to $\mathrm{BC}$ deposition in the Arctic in 2010. A recent study suggested that open fires that burned in western Greenland in summer (31 July to 21 August 2017) could potentially alter the Arctic air composition and foster glacier melting (Evangeliou et al., 2019). Although the footprint of Arctic surface BC showed a relatively weak sensitivity to areas such as forests and tundra, in the boreal regions pollutants from boreal wildfires could have greater effects on the Arctic air composition in summer under future warming scenarios (Veira et al., 2016).

\subsection{Sources of Arctic BC at high altitudes}

Arctic BC levels at high altitudes showed the highest levels in spring (March-April, 40.5-53.9 $\mathrm{ng} \mathrm{m}^{-3}$ ), followed by those in late autumn to early winter (November-January, 36.5- 


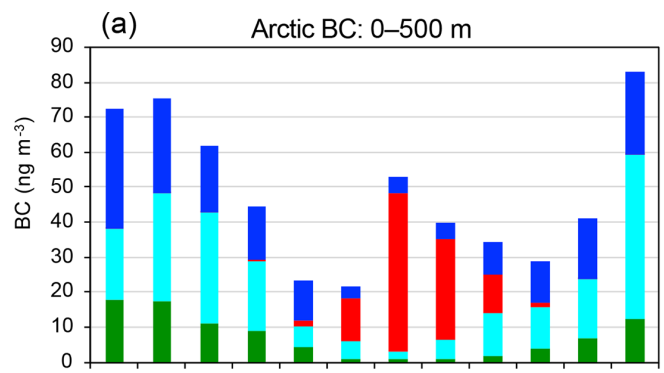

(b)
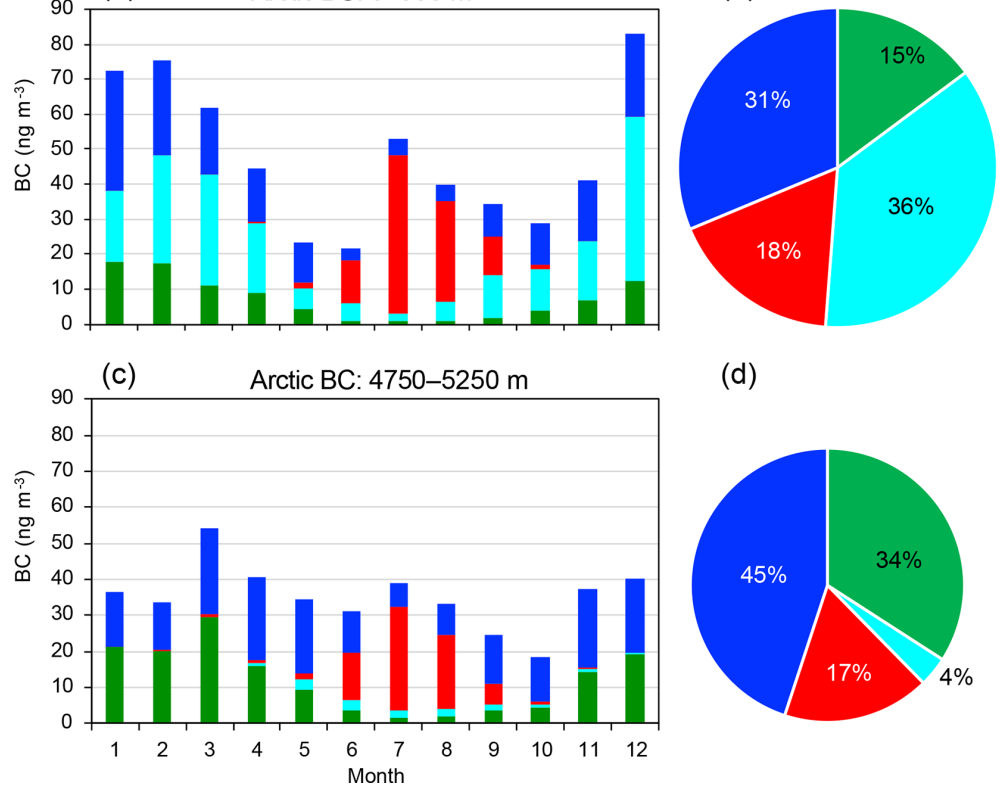

(d)

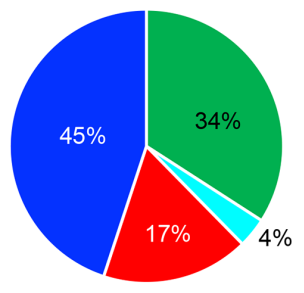

- Residential

- Gas flaring

- Open biomass

burning

- Others

Figure 5. Sectorial contributions from residential combustion (including fossil fuel and biofuel combustions), gas flaring, open biomass burning and others (energy other than gas flaring, industry, and transport) to (a) seasonal variations in Arctic surface BC, (b) annual mean Arctic surface BC, (c) seasonal variations in Arctic BC at high altitudes, and (d) annual mean of Arctic BC at high altitudes.

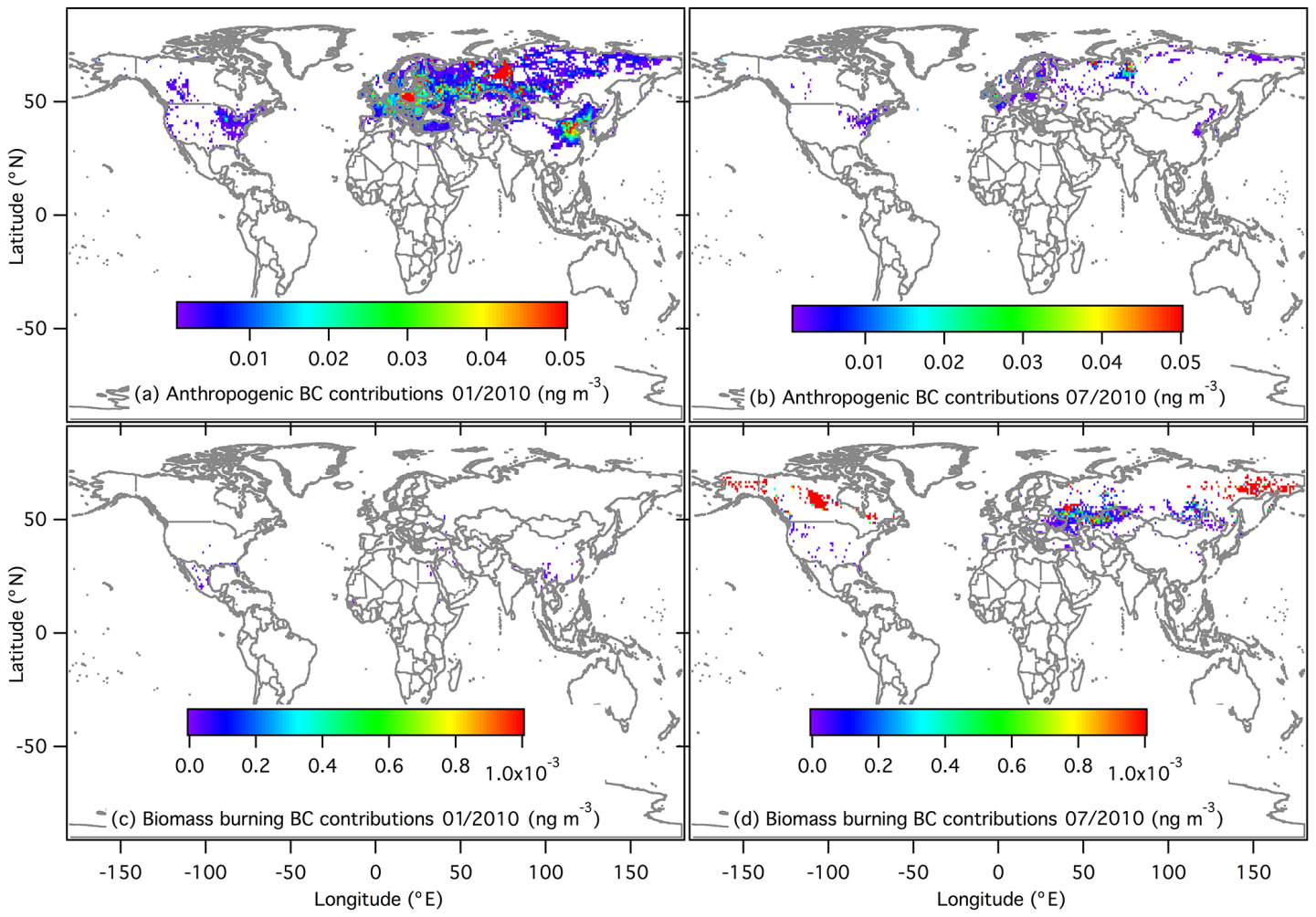

Figure 6. Spatial distributions of contributions to Arctic BC at surface for (a) anthropogenic contributions in January 2010, (b) anthropogenic contributions in July 2010, (c) open biomass burning contributions in January 2010, and (d) open biomass burning contributions in July 2010. 


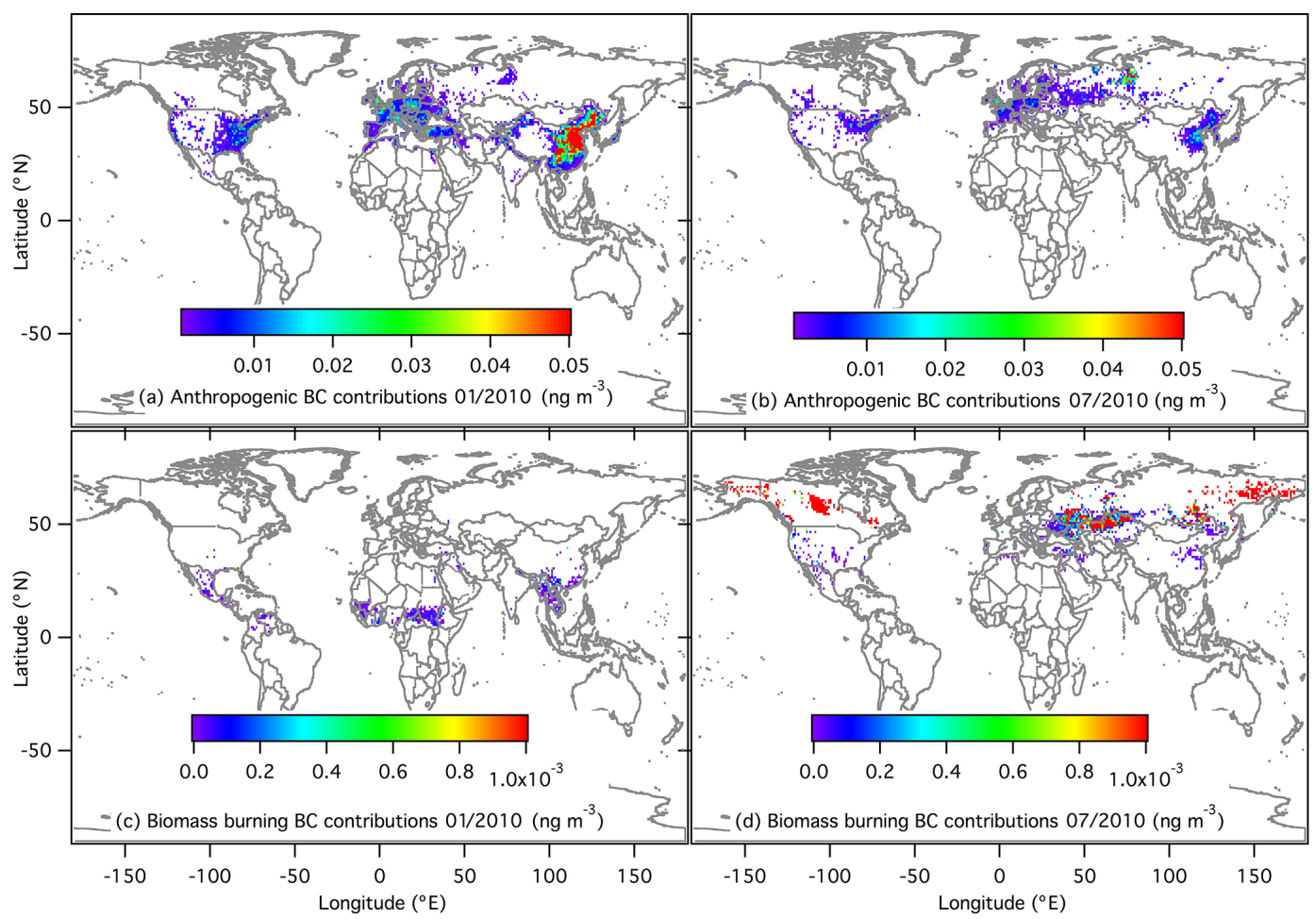

Figure 7. Spatial distributions of contributions to Arctic BC at high altitudes for (a) anthropogenic contributions in January 2010, (b) anthropogenic contributions in July 2010, (c) open biomass burning contributions in January 2010, and (d) open biomass burning contributions in July 2010.

$40.0 \mathrm{ng} \mathrm{m}^{-3}$ ), and summer (July-August, $33.0-39.0 \mathrm{ng} \mathrm{m}^{-3}$ ) (Fig. 4c). The annual mean Arctic BC at high altitudes was estimated to be $35.2 \mathrm{ng} \mathrm{m}^{-3}$, which is ca. $73 \%$ of those at the surface. Such a vertical profile is in accordance with those based on aircraft measurements over the Canadian High Arctic (Schulz et al., 2019). Similarly to the case for the surface, anthropogenic sources dominated by the residential, transport, industry, and energy sectors (excluding gas flaring) accounted for $94 \%-100 \%$ of Arctic BC at high altitudes in October-May (Figs. 4c and 5c). East Asia accounted for $34 \%-65 \%$ of the total BC in October-May (40\% annually). In comparison, using the Community Atmosphere Model version 5 driven by the NASA Modern Era RetrospectiveAnalysis for Research and Applications (MERRA) reanalysis data and the IPCC AR5 year 2000 BC emission inventory, H. Wang et al. (2014) found that East Asia accounted for $23 \%$ of BC burden in the Arctic for 1995-2005. In summer, open biomass burning in the boreal regions accounted for $40 \%-72 \%$ ( $57 \%$ on average) of Arctic BC at high altitudes, similar to the source contributions to Arctic surface BC. Specifically, open biomass burning sources from Siberia accounted for $40 \%-42 \%$ of Arctic BC at high altitudes in July-August. Annually, anthropogenic sources and open biomass burning accounted for $83 \%$ (in which residential sources accounted for $34 \%$ ) and $17 \%$, respectively, of total Arctic BC at high altitudes (Figs. 4d and 5d).
Further investigations of geospatial contributions to Arctic BC at high altitudes in January and July provided more details regarding BC sources. In January, the main anthropogenic BC source in East Asia covered a wide range in China (Fig. 7a). Not only east and northeast China but also southwest China (Sichuan and Guizhou provinces) were the major anthropogenic sources of Arctic BC at high altitudes. In July, anthropogenic sources made a relatively weak contribution to Arctic $\mathrm{BC}$ at high altitudes. The regions that were sources of open biomass burning contributions to Arctic BC at high altitudes were mainly the far east of Siberia, Kazakhstan, central Canada, and Alaska, i.e., similar to the sources of Arctic surface BC. Unlike Arctic surface BC, for which the dominant source regions are at high latitudes in both winter and summer, Arctic BC at high altitudes mainly originates from mid-latitude regions (Figs. 6 and 7). In terms of transport pathways, air masses could be uplifted at lowto-mid latitudes and transported to the Arctic (Stohl, 2006). Further investigations are needed to obtain more details of the transport processes.

\subsection{Comparison of FLEXPART and GEOS-Chem simulations of $\mathrm{BC}$ sources}

Data for BC sources simulated with FLEXPART were compared with those obtained with GEOS-Chem (Ikeda et al., 
2017), which is an Eulerian atmospheric transport model, using the same emission inventories. The simulated seasonal variations in Arctic BC levels and source contributions obtained with FLEXPART agreed well with those obtained with GEOS-Chem (Fig. S3). The annual mean BC levels at the Arctic surface obtained by FLEXPART and GEOS-Chem simulations were 48 and $70 \mathrm{ng} \mathrm{m}^{-3}$, respectively; the highaltitude values simulated by FLEXPART and GEOS-Chem were 35 and $38 \mathrm{ng} \mathrm{m}^{-3}$, respectively. The magnitude difference between the BC levels at the Arctic surface could be related to meteorology. ECMWF ERA-Interim data were used as the input for the FLEXPART simulation, whereas the GEOS-Chem simulation was driven by assimilated meteorological data from the Goddard Earth Observation System (GEOS-5).

The treatments of the $\mathrm{BC}$ removal processes could also lead to different simulation results, depending on the model. In terms of $\mathrm{BC}$ loss processes, dry and wet depositions were the removal pathways, depending on the particle size and density, in FLEXPART. The treatment of meteorology, especially cloud water and precipitation, would therefore affect the uncertainties of the simulations. In FLEXPART version 10.1, BC particles are separately parameterized as ice nuclei for ice clouds, cloud condensation nuclei for liquidwater clouds, and $90 \%$ as cloud condensation nuclei for mixed-phase clouds. The separation of mixed-phase clouds is realistic, as $77 \%$ of in-cloud scavenging processes occurred in the mixed phase over a $90 \mathrm{~d}$ period starting from December 2006 (Grythe et al., 2017).

In GEOS-Chem simulations, the BC aging was parameterized based on the number concentration of $\mathrm{OH}$ radicals (Liu et al., 2011). The BC was assumed to be hydrophilic in liquid clouds ( $T \geq 258 \mathrm{~K}$ ) and hydrophobic when serving as ice nuclei in ice clouds ( $T<258 \mathrm{~K})$ (Wang et al., 2011), with modifications because the scavenging rate of hydrophobic $\mathrm{BC}$ was reduced to $5 \%$ of water-soluble aerosols for liquid clouds (Bourgeois and Bey, 2011). Such a treatment is expected to improve the simulation accuracy (Ikeda et al., 2017).

In Lagrangian models, the trajectories of particles are computed by following the movement of air masses with no numerical diffusion, although some artificial numerical errors could be generated from stochastic differential equations (Ramli and Esler, 2016). As a result, long-range transport processes can be well simulated (Stohl, 2006; Stohl et al., 2013). In comparison, Eulerian chemical transport models such as GEOS-Chem have the advantage of simulating nonlinear processes on the global scale, which enables treatment of the $\mathrm{BC}$ aging processes (coating with soluble components) (Bey et al., 2001; Eastham et al., 2018). However, with GEOS-Chem, the capture of intercontinental pollution plumes is difficult because of numerical plume dissipation (Rastigejev et al., 2010). Nevertheless, the agreement between the FLEXPART and GEO-Chem simulations of $\mathrm{BC}$ source contributions indicates improved reliability of evaluated source contributions to Arctic BC.

\section{Conclusions}

The source contributions to Arctic BC were investigated by using a FLEXPART (version 10.1) transport model that incorporated emission inventories. FLEXPART-simulated BC data agreed well with observations at Arctic sites, i.e., Utqiagivik, Alert, Zeppelin, and Tiksi. The source regions and source sectors of $\mathrm{BC}$ at the surface and high altitudes over a wide region in the Arctic north of $66^{\circ} \mathrm{N}$ were simulated. $\mathrm{BC}$ at the Arctic surface was sensitive to local emissions and those from nearby Nordic countries $\left(>60^{\circ} \mathrm{N}\right)$. These results emphasize the role of anthropogenic emissions such as gas flaring and development of the Northern Sea Route in affecting air quality and climate change in the Arctic. Anthropogenic emissions in the northern regions of Russia were the main source $(56 \%)$ of Arctic surface BC annually. In contrast, $\mathrm{BC}$ in the Arctic at high altitudes was sensitive to midlatitude emissions $\left(30-60^{\circ} \mathrm{N}\right)$. Although they are geospatially far from the Arctic, anthropogenic emissions in East Asia made a notable (40\%) contribution to BC in the Arctic at high altitudes annually. Open biomass burning emissions, which were mainly from Siberia, Alaska, and Canada, were important in summer, contributing $56 \%-85 \%$ of $\mathrm{BC}$ at the Arctic surface and $40 \%-72 \%$ at Arctic high altitudes. Future increases in wildfires as a result of global warming could therefore increase the air pollution level during the Arctic summer. This study clarifies the source regions and sectors of BC in the Arctic. This information is fundamental for understanding and tackling air pollution and climate change in the region.

Data availability. The data set for simulated footprint and $\mathrm{BC}$ source contributions is available upon request to the corresponding author.

Supplement. The supplement related to this article is available online at: https://doi.org/10.5194/acp-20-1641-2020-supplement.

Author contributions. CZ and YK designed the study. CZ, MT, and IP optimized the FLEXPART model. CZ performed FLEXPART model simulations, conducted analyses, and wrote the paper. KI and HT provided data for GEOS-Chem simulations and site observations. All authors made comments that improved the paper.

Competing interests. The authors declare that they have no conflict of interest. 
Acknowledgements. We acknowledge staff from the following universities and agencies for BC observational data: Utqiagvik and Tiksi sites are operated by the National Oceanic and Atmospheric Administration; the Zeppelin site is operated by Stockholm University; and the Alert site is operated by Environment and Climate Change Canada. We are grateful to Chandra Mouli Pavuluri (Tianjin University) and an anonymous reviewer for the comments. We thank Helen McPherson, $\mathrm{PhD}$, from Edanz Group (https://en-author-services.edanzgroup.com/ ?utm_source=ack\&utm_medium=journal, last access: 10 February 2020) for editing a draft of this paper.

Financial support. This research has been supported by the Environmental Research and Technology Development Fund, MOEJ (grant no. 2-1505).

Review statement. This paper was edited by Hailong Wang and reviewed by Chandra Mouli Pavuluri and one anonymous referee.

\section{References}

AMAP Assessment 2015: Black carbon and ozone as Arctic climate forcers, Arctic Monitoring and Assessment Programme (AMAP), Oslo, Norway, 2015.

Bey, I., Jacob, D. J., Yantosca, R. M., Logan, J. A., Field, B. D., Fiore, A. M., Li, Q. B., Liu, H. G. Y., Mickley, L. J., and Schultz, M. G.: Global modeling of tropospheric chemistry with assimilated meteorology: Model description and evaluation, J. Geophys. Res.-Atmos., 106, 23073-23095, https://doi.org/10.1029/2001jd000807, 2001.

Bond, T. C., Streets, D. G., Yarber, K. F., Nelson, S. M., Woo, J. H., and Klimont, Z.: A technology-based global inventory of black and organic carbon emissions from combustion, J. Geophys. Res., 109, D14203, https://doi.org/10.1029/2003JD003697, 2004.

Bond, T. C., Bhardwaj, E., Dong, R., Jogani, R., Jung, S. K., Roden, C., Streets, D. G., and Trautmann, N. M.: Historical emissions of black and organic carbon aerosol from energy-related combustion, 1850-2000, Global Biogeochem. Cy., 21, Gb2018, https://doi.org/10.1029/2006GB002840, 2007.

Bourgeois, Q. and Bey, I.: Pollution transport efficiency toward the Arctic: sensitivity to aerosol scavenging and source regions, J. Geophys. Res., 116, D08213, https://doi.org/10.1029/2010JD015096, 2011.

Brock, C. A., Cozic, J., Bahreini, R., Froyd, K. D., Middlebrook, A. M., McComiskey, A., Brioude, J., Cooper, O. R., Stohl, A., Aikin, K. C., de Gouw, J. A., Fahey, D. W., Ferrare, R. A., Gao, R. S., Gore, W., Holloway, J. S., Hubler, G., Jefferson, A., Lack, D. A., Lance, S., Moore, R. H., Murphy, D. M., Nenes, A., Novelli, P. C., Nowak, J. B., Ogren, J. A., Peischl, J., Pierce, R. B., Pilewskie, P., Quinn, P. K., Ryerson, T. B., Schmidt, K. S., Schwarz, J. P., Sodemann, H., Spackman, J. R., Stark, H., Thomson, D. S., Thornberry, T., Veres, P., Watts, L. A., Warneke, C., and Wollny, A. G.: Characteristics, sources, and transport of aerosols measured in spring 2008 during the aerosol, radiation, and cloud processes affecting Arc- tic Climate (ARCPAC) Project, Atmos. Chem. Phys., 11, 2423 2453, https://doi.org/10.5194/acp-11-2423-2011, 2011.

Cohen, J., Screen, J. A., Furtado, J. C., Barlow, M., Whittleston, D., Coumou, D., Francis, J., Dethloff, K., Entekhabi, D., Overland, J., and Jones, J.: Recent Arctic amplification and extreme mid-latitude weather, Nat. Geosci., 7, 627-637, https://doi.org/10.1038/Ngeo2234, 2014.

Cooke, W. F. and Wilson, J. J. N.: A global black carbon aerosol model, J. Geophys. Res.-Atmos., 101, 19395-19409, 1996.

Cozic, J., Verheggen, B., Mertes, S., Connolly, P., Bower, K., Petzold, A., Baltensperger, U., and Weingartner, E.: Scavenging of black carbon in mixed phase clouds at the high alpine site Jungfraujoch, Atmos. Chem. Phys., 7, 1797-1807, https://doi.org/10.5194/acp-7-1797-2007, 2007.

Dong, X., Zhu, Q., Fu, J. S., Huang, K., Tan, J., and Tipton, M.: Evaluating recent updated black carbon emissions and revisiting the direct radiative forcing in Arctic, Geophys. Res. Lett., 46, 3560-3570, https://doi.org/10.1029/2018GL081242, 2019.

Eastham, S. D., Long, M. S., Keller, C. A., Lundgren, E., Yantosca, R. M., Zhuang, J. W., Li, C., Lee, C. J., Yannetti, M., Auer B. M., Clune, T. L., Kouatchou, J., Putman, W. M., Thompson, M. A., Trayanov, A. L., Molod, A. M., Martin, R. V., and Jacob, D. J.: GEOS-Chem High Performance (GCHP v11-02c): a next-generation implementation of the GEOS-Chem chemical transport model for massively parallel applications, Geosci. Model Dev., 11, 2941-2953, https://doi.org/10.5194/gmd-112941-2018, 2018.

Eckhardt, S., Quennehen, B., Olivie, D. J. L., Berntsen, T. K., Cherian, R., Christensen, J. H., Collins, W., Crepinsek, S., Daskalakis, N., Flanner, M., Herber, A., Heyes, C., Hodnebrog, O., Huang, L., Kanakidou, M., Klimont, Z., Langner, J., Law, K. S., Lund, M. T., Mahmood, R., Massling, A., Myriokefalitakis, S., Nielsen, I. E., Nojgaard, J. K., Quaas, J., Quinn, P. K., Raut, J. C., Rumbold, S. T., Schulz, M., Sharma, S., Skeie, R. B., Skov, H., Uttal, T., von Salzen, K., and Stohl, A.: Current model capabilities for simulating black carbon and sulfate concentrations in the Arctic atmosphere: a multi-model evaluation using a comprehensive measurement data set, Atmos. Chem. Phys., 15, 9413-9433, https://doi.org/10.5194/acp-15-9413-2015, 2015.

Evangeliou, N., Balkanski, Y., Hao, W. M., Petkov, A., Silverstein, R. P., Corley, R., Nordgren, B. L., Urbanski, S. P., Eckhardt, S., Stohl, A., Tunved, P., Crepinsek, S., Jefferson, A., Sharma, S., Nojgaard, J. K., and Skov, H.: Wildfires in northern Eurasia affect the budget of black carbon in the Arctic - a 12-year retrospective synopsis (2002-2013), Atmos. Chem. Phys., 16, 75877604, https://doi.org/10.5194/acp-16-7587-2016, 2016.

Evangeliou, N., Kylling, A., Eckhardt, S., Myroniuk, V., Stebel, K., Paugam, R., Zibtsev, S., and Stohl, A.: Open fires in Greenland in summer 2017: transport, deposition and radiative effects of BC, OC and BrC emissions, Atmos. Chem. Phys., 19, 1393-1411, https://doi.org/10.5194/acp-19-1393-2019, 2019.

Filimonova, I. V., Komarova, A. V., Eder, L. V., and Provornaya, I. V.: State instruments for the development stimulation of Arctic resources regions, IOP Conf. Ser.: Earth Environ. Sci., 193, 012069, https://doi.org/10.1088/1755-1315/193/1/012069, 2018.

Garrett, T. J., Brattstrom, S., Sharma, S., Worthy, D. E. J., and Novelli, P.: The role of scavenging in the seasonal transport of black carbon and sulfate to the Arctic, Geophys. Res. Lett., 38, L16805, https://doi.org/10.1029/2011gl048221, 2011. 
Grythe, H., Kristiansen, N. I., Zwaaftink, C. D. G., Eckhardt, S., Strom, J., Tunved, P., Krejci, R., and Stohl, A.: A new aerosol wet removal scheme for the Lagrangian particle model FLEXPART v10, Geosci. Model Dev., 10, 1447-1466, https://doi.org/10.5194/gmd-10-1447-2017, 2017.

Hegg, D. A., Clarke, A. D., Doherty, S. J., and Ström, J.: Measurements of black carbon aerosol washout ratio on Svalbard, Tellus B, 63, 891-900, https://doi.org/10.1111/j.16000889.2011.00577.x, 2011.

Hertel, O., Christensen, J. Runge, E. H., Asman, W. A. H., Berkowicz, R., Hovmand, M. F., and Hov, O.: Development and testing of a new variable scale air pollution model - ACDEP, Atmos. Environ., 29, 1267-1290, 1995.

Hirdman, D., Burkhart, J. F., Sodemann, H., Eckhardt, S., Jefferson, A., Quinn, P. K., Sharma, S., Strom, J., and Stohl, A.: Long-term trends of black carbon and sulphate aerosol in the Arctic: changes in atmospheric transport and source region emissions, Atmos. Chem. Phys., 10, 9351-9368, https://doi.org/10.5194/acp-109351-2010, 2010.

Huang, K. and Fu, J. S.: A global gas flaring black carbon emission rate dataset from 1994 to 2012, Scient. Data, 3, 160104, https://doi.org/10.1038/sdata.2016.104, 2016.

Huang, K., Fu, J. S., Prikhodko, V. Y., Storey, J. M., Romanov, A., Hodson, E. L., Cresko, J., Morozova, I., Ignatieva, Y., and Cabaniss, J.: Russian anthropogenic black carbon: Emission reconstruction and Arctic black carbon simulation, J. Geophys. Res.-Atmos., 120, 11306-11333, https://doi.org/10.1002/2015jd023358, 2015.

Ikeda, K., Tanimoto, H., Sugita, T., Akiyoshi, H., Kanaya, Y., Zhu, C. M., and Taketani, F.: Tagged tracer simulations of black carbon in the Arctic: transport, source contributions, and budget, Atmos. Chem. Phys., 17, 10515-10533, https://doi.org/10.5194/acp-17-10515-2017, 2017.

Ikeda, K., Tanimoto, H., Sugita, T., Akiyoshi, H., Clerbaux, C., and Coheur, P. F.: Model and satellite analysis of transport of Asian anthropogenic pollution to the Arctic: Siberian and Pacific pathways, and their meteorological controls, J. Geophys. Res., in review, 2020.

Janssens-Maenhout, G., Crippa, M., Guizzardi, D., Dentener, F., Muntean, M., Pouliot, G., Keating, T., Zhang, Q., Kurokawa, J., Wankmüller, R., Denier van der Gon, H., Kuenen, J. J. P., Klimont, Z., Frost, G., Darras, S., Koffi, B., and Li, M.: HTAP_v2.2: a mosaic of regional and global emission grid maps for 2008 and 2010 to study hemispheric transport of air pollution, Atmos. Chem. Phys., 15, 11411-11432, https://doi.org/10.5194/acp-15-11411-2015, 2015.

Keegan, K. M., Albert, M. R., McConnell, J. R., and Baker, I.: Climate change and forest fires synergistically drive widespread melt events of the Greenland Ice Sheet, P. Natl. Acad. Sci. USA, 111, 7964-7967, https://doi.org/10.1073/pnas.1405397111, 2014.

Kipling, Z., Stier, P., Schwarz, J. P., Perring, A. E., Spackman, J. R., Mann, G. W., Johnson, C. E., and Telford, P. J.: Constraints on aerosol processes in climate models from vertically-resolved aircraft observations of black carbon, Atmos. Chem. Phys., 13, 5969-5986, https://doi.org/10.5194/acp-13-5969-2013, 2013.

Kirchstetter, T. W., Novakov, T., and Hobbs, P. V.: Evidence that the spectral dependence of light absorption by aerosols is affected by organic carbon, J. Geophys. Res.-Atmos., 109, D21208, https://doi.org/10.1029/2004jd004999, 2004.

Klimont, Z., Kupiainen, K., Heyes, C., Purohit, P., Cofala, J., Rafaj, P., Borken-Kleefeld, J., and Schöpp, W.: Global anthropogenic emissions of particulate matter including black carbon, Atmos. Chem. Phys., 17, 8681-8723, https://doi.org/10.5194/acp-178681-2017, 2017.

Klonecki, A., Hess, P., Emmons, L., Smith, L., Orlando, J., and Blake, D.: Seasonal changes in the transport of pollutants into the Arctic troposphere-model study, J. Geophys. Res.-Atmos., 108, 8367, https://doi.org/10.1029/2002jd002199, 2003.

Koch, D. and Hansen, J.: Distant origins of Arctic black carbon: A Goddard Institute for Space Studies ModelE experiment, J. Geophys. Res.-Atmos., 110, D04204, https://doi.org/10.1029/2004jd005296, 2005.

Koch, D., Schmidt, G. A., and Field, C. V.: Sulfur, sea salt, and radionuclide aerosols in GISS ModelE, J. Geophys. Res., 111, D06206, https://doi.org/10.1029/2004jd005550, 2006.

Lack, D. A. and Langridge, J. M.: On the attribution of black and brown carbon light absorption using the Angstrom exponent, Atmos. Chem. Phys., 13, 10535-10543, https://doi.org/10.5194/acp-13-10535-2013, 2013.

Law, K. S. and Stohl, A.: Arctic air pollution: Origins and impacts, Science, 315, 1537-1540, https://doi.org/10.1126/science.1137695, 2007.

Liu, D., Quennehen, B., Darbyshire, E., Allan, J. D., Williams, P. I., Taylor, J. W., Bauguitte, S. J. B., Flynn, M. J., Lowe, D., Gallagher, M. W., Bower, K. N., Choularton, T. W., and Coe, H.: The importance of Asia as a source of black carbon to the European Arctic during springtime 2013, Atmos. Chem. Phys., 15, 1153711555, https://doi.org/10.5194/acp-15-11537-2015, 2015.

Liu, J., Fan, S., Horowitz, L. W., and Levy II, H.: Evaluation of factors controlling long-range transport of black carbon to the Arctic, J. Geophys. Res., 116, D00A14, https://doi.org/10.1029/2010JD015145, 2011.

Ma, P.-L., Gattiker, J. R., Liu, X., and Rasch, P. J.: A novel approach for determining source-receptor relationships in model simulations: a case study of black carbon transport in northern hemisphere winter, Environ. Res. Lett., 8, 024042 , https://doi.org/10.1088/1748-9326/8/2/024042, 2013.

McMahon, T. A. and Denison, P. J.: Empirical atmospheric deposition parameters - a survey, Atmos. Environ., 13, 571-585, https://doi.org/10.1016/0004-6981(79)90186-0, 1979.

Najafi, M. R., Zwiers, F. W., and Gillett, N. P.: Attribution of Arctic temperature change to greenhouse-gas and aerosol influences, Nat. Clim. Change, 5, 246-249, https://doi.org/10.1038/Nclimate2524, 2015.

Qi, L., Li, Q. B., Henze, D. K., Tseng, H. L., and He, C. L.: Sources of springtime surface black carbon in the Arctic: an adjoint analysis for April 2008, Atmos. Chem. Phys., 17, 96979716, https://doi.org/10.5194/acp-17-9697-2017, 2017.

Quinn, P. K., Bates, T. S., Baum, E., Doubleday, N., Fiore, A. M., Flanner, M., Fridlind, A., Garrett, T. J., Koch, D., Menon, S., Shindell, D., Stohl, A., and Warren, S. G.: Shortlived pollutants in the Arctic: their climate impact and possible mitigation strategies, Atmos. Chem. Phys., 8, 1723-1735, https://doi.org/10.5194/acp-8-1723-2008, 2008.

Ramli, H. M. and Esler, J. G.: Quantitative evaluation of numerical integration schemes for Lagrangian particle dispersion models, 
Geosci. Model Dev., 9, 2441-2457, https://doi.org/10.5194/gmd9-2441-2016, 2016.

Rastigejev, Y., Park, R., Brenner, M., and Jacob, D.: Resolving intercontinental pollution plumes in global models of atmospheric transport, J. Geophys. Res., 115, D02302, https://doi.org/10.1029/2009JD012568, 2010.

Roiger, A., Thomas, J. L., Schlager, H., Law, K. S., Kim, J., Schafler, A., Weinzierl, B., Dahloktter, F., Krisch, I., Marelle, L., Minikin, A., Raut, J. C., Reiter, A., Rose, M., Scheibe, M., Stock, P., Baumann, R., Bouapar, I., Clerbaux, C., George, M., Onishi, I., and Flemming, J.: Quantifying emerging local anthropogenic emissions in the Arctic region: The ACCESS aircraft campaign experiment, B. Am. Meteorol. Soc., 96, 441-460, https://doi.org/10.1175/Bams-D-13-00169.1, 2015.

Sand, M., Berntsen, T. K., von Salzen, K., Flanner, M. G., Langner, J., and Victor, D. G.: Response of Arctic temperature to changes in emissions of short-lived climate forcers, Nat. Clim. Change, 6, 286-289, https://doi.org/10.1038/Nclimate2880, 2016.

Schacht, J., Heinold, B., Quaas, J., Backman, J., Cherian, R., Ehrlich, A., Herber, A., Huang, W. T. K., Kondo, Y., Massling, A., Sinha, P. R., Weinzierl, B., Zanatta, M., and Tegen, I.: The importance of the representation of air pollution emissions for the modeled distribution and radiative effects of black carbon in the Arctic, Atmos. Chem. Phys., 19, 11159-11183, https://doi.org/10.5194/acp-19-11159-2019, 2019.

Schmale, J., Arnold, S. R., Law, K. S., Thorp, T., Anenberg, S., Simpson, W. R., Mao, J., and Pratt, K. A.: Local Arctic Air Pollution: A Neglected but Serious Problem, Earth's Future, 6, 13851412, https://doi.org/10.1029/2018ef000952, 2018.

Schulz, H., Zanatta, M., Bozem, H., Leaitch, W. R., Herber, A. B., Burkart, J., Willis, M. D., Kunkel, D., Hoor, P. M., Abbatt, J. P. D., and Gerdes, R.: High Arctic aircraft measurements characterising black carbon vertical variability in spring and summer, Atmos. Chem. Phys., 19, 2361-2384, https://doi.org/10.5194/acp19-2361-2019, 2019.

Sharma, S., Leaitch, W. R., Huang, L., Veber, D., Kolonjari, F., Zhang, W., Hanna, S. J., Bertram, A. K., and Ogren, J. A.: An evaluation of three methods for measuring black carbon in Alert, Canada, Atmos. Chem. Phys., 17, 15225-15243, https://doi.org/10.5194/acp-17-15225-2017, 2017.

Shaw, G. E.: The arctic haze phenomenon, B. Am. Meteorol. Soc., 76, 2403-2413, 1995.

Shen, Z. Y., Ming, Y., Horowitz, L. W., Ramaswamy, V., and Lin, M. Y.: On the seasonality of Arctic black carbon, J. Climate, 30, 4429-4441, https://doi.org/10.1175/Jcli-D-16-0580.1, 2017.

Shindell, D. T., Chin, M., Dentener, F., Doherty, R. M., Faluvegi, G., Fiore, A. M., Hess, P., Koch, D. M., MacKenzie, I. A., Sanderson, M. G., Schultz, M. G., Schulz, M., Stevenson, D. S., Teich, H., Textor, C., Wild, O., Bergmann, D. J., Bey, I., Bian, H., Cuvelier, C., Duncan, B. N., Folberth, G., Horowitz, L. W., Jonson, J., Kaminski, J. W., Marmer, E., Park, R., Pringle, K. J., Schroeder, S., Szopa, S., Takemura, T., Zeng, G., Keating, T. J., and Zuber, A.: A multi-model assessment of pollution transport to the Arctic, Atmos. Chem. Phys., 8, 5353-5372, https://doi.org/10.5194/acp-8-5353-2008, 2008.

Sinha, P. R., Kondo, Y., Koike, M., Ogren, J. A., Jefferson, A., Barrett, T. E., Sheesley, R. J., Ohata, S., Moteki, N., Coe, H., Liu, D., Irwin, M., Tunved, P., Quinn, P. K., and Zhao, Y.: Evaluation of ground-based black carbon measurements by filter-based photometers at two Arctic sites, J. Geophys. Res.-Atmos., 122, 3544-3572, https://doi.org/10.1002/2016jd025843, 2017.

Stohl, A.: Characteristics of atmospheric transport into the Arctic troposphere, J. Geophys. Res.-Atmos., 111, D11306, https://doi.org/10.1029/2005jd006888, 2006.

Stohl, A., Hittenberger, M., and Wotawa, G.: Validation of the Lagrangian particle dispersion model FLEXPART against largescale tracer experiment data, Atmos. Environ., 32, 4245-4264, https://doi.org/10.1016/S1352-2310(98)00184-8, 1998.

Stohl, A., Forster, C., Frank, A., Seibert, P., and Wotawa, G.: Technical note: The Lagrangian particle dispersion model FLEXPART version 6.2, Atmos. Chem. Phys., 5, 2461-2474, https://doi.org/10.5194/acp-5-2461-2005, 2005.

Stohl, A., Klimont, Z., Eckhardt, S., Kupiainen, K., Shevchenko, V. P., Kopeikin, V. M., and Novigatsky, A. N.: Black carbon in the Arctic: the underestimated role of gas flaring and residential combustion emissions, Atmos. Chem. Phys., 13, 8833-8855, https://doi.org/10.5194/acp-13-8833-2013, 2013.

Taketani, F., Miyakawa, T., Takashima, H., Komazaki, Y., Pan, X., Kanaya, Y., and Inoue, J.: Shipborne observations of atmospheric black carbon aerosol particles over the Arctic Ocean, Bering Sea, and North Pacific Ocean during September 2014, J. Geophys. Res.-Atmos., 121, 1914-1921, https://doi.org/10.1002/2015jd023648, 2016.

Tilling, R. L., Ridout, A., Shepherd, A., and Wingham, D. J.: Increased Arctic sea ice volume after anomalously low melting in 2013, Nat. Geosci., 8, 643-646, https://doi.org/10.1038/Ngeo2489, 2015.

Tørseth, K., Aas, W., Breivik, K., Fjæraa, A. M., Fiebig, M., Hjellbrekke, A. G., Lund Myhre, C., Solberg, S., and Yttri, K. E.: Introduction to the European Monitoring and Evaluation Programme (EMEP) and observed atmospheric composition change during 1972-2009, Atmos. Chem. Phys., 12, 5447-5481, https://doi.org/10.5194/acp-12-5447-2012, 2012.

Trusel, L. D., Das, S. B., Osman, M. B., Evans, M. J., Smith, B., Fettweis, X., McConnell, J. R., Noel, B. P. Y., and van den Broeke, M. R.: Nonlinear rise in Greenland runoff in response to post-industrial Arctic warming, Nature, 564, 104-108, https://doi.org/10.1038/s41586-018-0752-4, 2018.

van der Werf, G. R., Randerson, J. T., Giglio, L., Collatz, G. J., Mu, M., Kasibhatla, P. S., Morton, D. C., DeFries, R. S., Jin, Y., and van Leeuwen, T. T.: Global fire emissions and the contribution of deforestation, savanna, forest, agricultural, and peat fires (1997-2009), Atmos. Chem. Phys., 10, 11707-11735, https://doi.org/10.5194/acp-10-11707-2010, 2010.

Veira, A., Lasslop, G., and Kloster, S.: Wildfires in a warmer climate: Emission fluxes, emission heights, and black carbon concentrations in 2090-2099, J. Geophys. Res.-Atmos., 121, 31953223, https://doi.org/10.1002/2015jd024142, 2016.

Wang, H., Easter, R. C., Rasch, P. J., Wang, M., Liu, X., Ghan, S. J., Qian, Y., Yoon, J. H., Ma, P. L., and Vinoj, V.: Sensitivity of remote aerosol distributions to representation of cloud-aerosol interactions in a global climate model, Geosci. Model Dev., 6, 765-782, https://doi.org/10.5194/gmd-6-765-2013, 2013.

Wang, H., Rasch, P. J., Easter, R. C., Singh, B., Zhang, R., Ma, P. L., Qian, Y., and Beagley, N.: Using an explicit emission tagging method in global modeling of source-receptor relationships for black carbon in the Arctic: Variations, Sources and Trans- 
port pathways, J. Geophys. Res.-Atmos., 119, 12888-12909, https://doi.org/10.1002/2014JD022297, 2014.

Wang, Q., Jacob, D. J., Fisher, J. A., Mao, J., Leibensperger, E. M., Carouge, C. C., Le Sager, P., Kondo, Y., Jimenez, J. L., Cubison, M. J., and Doherty, S. J.: Sources of carbonaceous aerosols and deposited black carbon in the Arctic in winter-spring: implications for radiative forcing, Atmos. Chem. Phys., 11, 1245312473, https://doi.org/10.5194/acp-11-12453-2011, 2011.

Wang, Q., Jacob, D. J., Spackman, J. R., Perring, A. E., Schwarz, J. P., Moteki, N., Marais, E. A., Ge, C., Wang, J., and Barrett, S. R. H.: Global budget and radiative forcing of black carbon aerosol: constraints from pole-to-pole (HIPPO) observations across the Pacific, J. Geophys. Res.-Atmos., 119, 195-206, https://doi.org/10.1002/2013JD020824, 2014.

Winiger, P., Andersson, A., Eckhardt, S., Stohl, A., and Gustafsson, O.: The sources of atmospheric black carbon at a European gateway to the Arctic, Nat. Commun., 7, 12776, https://doi.org/10.1038/ncomms12776, 2016.

Winiger, P., Barrett, T. E., Sheesley, R. J., Huang, L., Sharma, S., Barrie, L. A., Yttri, K. E., Evangeliou, N., Eckhardt, S., Stohl, A., Klimont, Z., Heyes, C., Semiletov, I. P., Dudarev, O. V., Charkin, A., Shakhova, N., Holmstrand, H., Andersson, A., and Gustafsson, O.: Source apportionment of circum-Arctic atmospheric black carbon from isotopes and modeling, Sci. Adv., 5, eaau8052, https://doi.org/10.1126/sciadv.aau8052, 2019.

Xu, J. W., Martin, R. V., Morrow, A., Sharma, S., Huang, L., Leaitch, W. R., Burkart, J., Schulz, H., Zanatta, M., Willis, M. D., Henze, D. K., Lee, C. J., Herber, A. B., and Abbatt, J. P. D.: Source attribution of Arctic black carbon constrained by aircraft and surface measurements, Atmos. Chem. Phys., 17, 1197111989, https://doi.org/10.5194/acp-17-11971-2017, 2017.
Yang, Y., Wang, H., Smith, S. J., Easter, R. C., and Rasch, P. J.: Sulfate aerosol in the Arctic: Source attribution and radiative forcing, J. Geophys. Res.-Atmos., 123, 1899-1918, https://doi.org/10.1002/2017JD027298, 2018.

Yang, Y., Smith, S. J., Wang, H., Mills, C. M., and Rasch, P. J.: Variability, timescales, and nonlinearity in climate responses to black carbon emissions, Atmos. Chem. Phys., 19, 2405-2420, https://doi.org/10.5194/acp-19-2405-2019, 2019.

Zhang, K., O'Donnell, D., Kazil, J., Stier, P., Kinne, S., Lohmann, U., Ferrachat, S., Croft, B., Quaas, J., Wan, H., Rast, S., and Feichter, J.: The global aerosol-climate model ECHAM-HAM, version 2: sensitivity to improvements in process representations, Atmos. Chem. Phys., 12, 8911-8949, https://doi.org/10.5194/acp-12-8911-2012, 2012.

Zhang, Q., Streets, D. G., Carmichael, G. R., He, K. B., Huo, H., Kannari, A., Klimont, Z., Park, I. S., Reddy, S., Fu, J. S., Chen, D., Duan, L., Lei, Y., Wang, L. T., and Yao, Z. L.: Asian emissions in 2006 for the NASA INTEX-B mission, Atmos. Chem. Phys., 9, 5131-5153, https://doi.org/10.5194/acp-9-5131-2009, 2009.

Zhu, C., Kobayashi, H., Kanaya, Y., and Saito, M.: Size-dependent validation of MODIS MCD64A1 burned area over six vegetation types in boreal Eurasia: Large underestimation in croplands, Scient. Rep., 7, 4181, https://doi.org/10.1038/s41598-017-03739-0, 2017. 